\title{
A BIOCHEMICAL APPROACH TO LACTATE DEHYDROGENASE IN ASCITIC/PLEURAL FLUID IN A TERTIARY CARE HOSPITAL
}

Vivek Sinha1 , Poonam Kachhawa²

${ }^{1}$ Associate Professor, Department of Biochemistry, Saraswathi Institute of Medical Sciences, Hapur, Uttar Pradesh, India.

${ }^{2}$ Assistant Professor, Department of Biochemistry, Saraswathi Institute of Medical Sciences, Hapur, Uttar Pradesh, India.

ABSTRACT
BACKGROUND
Lactate dehydrogenase (LDH) is an enzyme which is found in almost all living cells. LDH is a tetramer composed of two different
subunits, M and H. It catalyses the interconversion of lactate and pyruvate, as it interconverts NAD ${ }^{+}$and NADH.
The aim of this study was to evaluate the diagnostic significance of estimating lactate dehydrogenase in ascitic and pleural fluid.

\section{MATERIALS AND METHODS}

The current study was conducted in the department of biochemistry at Saraswathi Institute of Medical Sciences, Hapur. This descriptive study was performed on 60 subjects suffering from ascites/pleural effusion, who satisfy the inclusion and exclusion criteria. Since the duration of the study was less, patients were selected by convenience technique.

\section{RESULTS}

Estimating the fluid lactate dehydrogenase levels in patients presenting with ascites helps in differentiating between malignant and non-malignant effusions. It is highly sensitive (100\%) and highly specific (100\%). Estimating the fluid lactate dehydrogenase level in patients presenting with pleural effusion helps in differentiating between transudative and exudative effusions. It is highly sensitive (100\%) and highly specific (100\%).

\section{CONCLUSION}

Biochemical analysis of LDH in ascitic fluid helps in differentiating malignant and non-malignant aetiology (Negative Predictive Value $=100 \%$, Confidence Interval $=75.3-100 \%$ ).

\section{KEY WORDS}

Lactate Dehydrogenase, Ascites, Pericardial Effusion.

HOW TO CITE THIS ARTICLE: Sinha V, Kachhawa P. A biochemical approach to lactate dehydrogenase in ascitic/pleural fluid in a tertiary care hospital. J. Evolution Med. Dent. Sci. 2019;8(02):142-145, DOI: 10.14260/jemds/2019/31

\section{BACKGROUND}

Lactate Dehydrogenase (LDH) is a tetrameric molecule used to detect cell damage or cell death.[1-5] It is composed of four polypeptide chains. It is composed of five different polypeptide chains encoded by separate genes ( $M$ and $H$ ). $\mathrm{LDH}_{1}$ is composed of four $\mathrm{H}$ subunits, and $\mathrm{LDH}_{5}$ of four $\mathrm{M}$ subunits. The biochemical analysis of extravascular body fluids is considered an important clinical tool in the patient management plan.

\section{Aim}

To study the diagnostic significance of estimating lactate dehydrogenase in ascitic and pleural fluid.

\section{MATERIALS AND METHODS \\ Study Setting}

This descriptive study was performed on a minimum of 60 subjects suffering from Ascites/ Pleural Effusion, who satisfy the inclusion and exclusion criteria. The aetiology of the

'Financial or Other Competing Interest': None.

Submission 30-11-2018, Peer Review 02-01-2019,

Acceptance 08-01-2019, Published 14-01-2019.

Corresponding Author:

Poonam Kachhawa,

Assistant Professor, Department of Biochemistry,

Sarawathi Institute of Medical Sciences,

Anwarpur, Hapur, Uttar Pradesh, India.

E-mail:poonamkac@yahoo.com

DOI: $10.14260 /$ jemds $/ 2019 / 31$

\section{(c) $($ () $\ominus$}

subjects to be studied in our study has already been established as per the diagnostic criteria of the disease concerned. This study was conducted in the department of department of biochemistry at Saraswathi institute of medical sciences in the period of March 2016 to Jun 2018.

\section{Study Period}

March 2016 to Jun 2018.

\section{Study Design}

Descriptive study.

\section{Study Subjects}

This study will be performed on a minimum of 60 subjects suffering from Ascites/ Pleural Effusion, who satisfy the inclusion and exclusion criteria. The aetiology of the subjects to be studied in our study has already been established as per the diagnostic criteria of the disease concerned.

\section{Sample Size}

This study will be performed on a minimum of 60 subjects suffering from Ascites/ Pleural Effusion, who satisfy the inclusion and exclusion criteria. The aetiology of the subjects to be studied in our study has already been established as per the diagnostic criteria of the disease concerned. Sample size was also calculated by convenience. Pre-tested semistructured Questionnaire to assess: Socio-demographic characteristics of the study participants. Inclusion and exclusion criteria were also taken in to consideration. General physical and CVS examination in study subjects. 


\section{Inclusion Criteria}

- All cases of Ascites/ Pleural Effusion of larger duration.

- Rapid filling of both the serous sacs after tapping.

\section{Exclusion Criteria}

Patients suffering from one of the following conditions:

- Acute Myocardial Infarction.

- Haemolysis.

- Trauma.

- Pulmonary Embolism.

- Post-operative cases.

After taking informed consent and ethical clearances, all subjects in the study will be studied with reference to-

- A complete physical and medical examination.

- Basic Anthropometry.

- Blood Urea, Serum Creatinine, Serum Albumin, SGOT, SGPT, FBS.

- $\quad$ Ascitic fluid for Lactate Dehydrogenase.

- $\quad$ Pleural fluid for Lactate Dehydrogenase.

- Serum Lactate Dehydrogenase.

- Ascitic/Pleural fluid - Protein, albumin, sugar, cells, malignant cells (When indicated)

- USG Whole Abdomen.

- X-Ray Chest.

All biochemical investigations were done by semiautomated biochemistry analyzer. All assays were performed according to the respective manufacturer's instructions.

\section{Statistical Analysis}

Categorical variables were presented in number and percentage (\%) and continuous variables were presented as mean \pm SD and median. Statistical tests were applied as follows-

1. Quantitative variables were compared using Independent $\mathrm{T}$ test.

2. Qualitative variables were correlated using Chi-Square test.

3. The data was entered in MS Excel spreadsheet and analysis was done using SPSS.

Version 20.Data was entered in Microsoft excel and Descriptive statistical analysis was done. Results on categorical measurements are presented as Percentages. Significance is assessed at $5 \%$ level of significance. $p$ value $<0.001$ statistically significant. Fisher's exact test/ Chi square test was used to find out the significance of study parameters on a categorical scale between two groups.

\section{RESULTS}

Estimating the fluid Lactate Dehydrogenase levels in patients presenting with ascites helps in differentiating between malignant and non-malignant effusion. It is highly sensitive (100\%) and highly specific (100\%).Estimating the fluid Lactate Dehydrogenase level in patients presenting with pleural effusion helps in differentiating between transudative and exudative effusion. It is highly sensitive $(100 \%)$ and highly specific (100\%).

\begin{tabular}{|c|c|c|c|}
\hline & $\begin{array}{c}\text { Ascitic Fluid } \\
\text { Malignant }\end{array}$ & \begin{tabular}{c|} 
Ascitic Fluid \\
Non-Malignant
\end{tabular} & p-Value \\
\hline \multicolumn{3}{|c|}{ 1. Age } & \multirow{6}{*}{0.052} \\
\hline Sample Size & 12 & 18 & \\
\hline Mean \pm S.D. & $47.5 \pm 11.09$ & $55.78 \pm 10.82$ & \\
\hline Median & 45 & 53.5 & \\
\hline Min-Max & $34-70$ & $42-75$ & \\
\hline $\begin{array}{l}\text { Inter Quartile } \\
\text { Range }\end{array}$ & $39-55.500$ & $45-65$ & \\
\hline \multicolumn{3}{|c|}{ 2. Ascitic Albumin } & \multirow{6}{*}{0.003} \\
\hline Sample Size & 12 & 18 & \\
\hline Mean \pm S.D. & $2.38 \pm 0.25$ & $1.82 \pm 0.67$ & \\
\hline Median & 2.35 & 2.05 & \\
\hline Min-Max & $2-2.8$ & $0.8-2.7$ & \\
\hline $\begin{array}{l}\text { Inter Quartile } \\
\text { Range }\end{array}$ & $2.200-2.600$ & $1.900-2.300$ & \\
\hline \multicolumn{3}{|c|}{ 3. Ascitic LDH } & \multirow{6}{*}{$<0.001$} \\
\hline Sample Size & 12 & 18 & \\
\hline Mean \pm S.D. & $523.58 \pm 127.62$ & $142.56 \pm 42.6$ & \\
\hline Median & 473 & 145.5 & \\
\hline Min-Max & $384-724$ & 18-195 & \\
\hline $\begin{array}{c}\text { Inter Quartile } \\
\text { Range }\end{array}$ & $409.50-636$ & $126-173$ & \\
\hline \multicolumn{3}{|c|}{ 4. Serum Albumin } & \multirow{6}{*}{0.003} \\
\hline Sample Size & 12 & 18 & \\
\hline Mean \pm S.D. & $3.23 \pm 0.27$ & $3.94 \pm 0.62$ & \\
\hline Median & 3.25 & 3.85 & \\
\hline Min-Max & $2.8-3.7$ & 3.5 & \\
\hline $\begin{array}{l}\text { Inter Quartile } \\
\text { Range }\end{array}$ & $3-3.450$ & $3.500-4.300$ & \\
\hline
\end{tabular}

\begin{tabular}{|c|c|c|c|c|c|}
\hline & & $\begin{array}{c}\text { Ascitic } \\
\text { Fluid } \\
\text { Malignant }\end{array}$ & $\begin{array}{c}\text { Ascitic } \\
\text { Fluid } \\
\text { Non- } \\
\text { Malignant }\end{array}$ & Total & P Value \\
\cline { 1 - 5 } Age & $1) \leq 50$ & $66.67 \%$ & $50.0 \%$ & 17 & \\
\cline { 2 - 5 } Total & $2) \geq 50$ & $33.33 \%$ & $50.0 \%$ & 13 & \\
\cline { 1 - 5 } & & $\begin{array}{c}12 \\
(100 \%)\end{array}$ & $\begin{array}{c}18 \\
(100 \%)\end{array}$ & $\begin{array}{c}30 \\
(100 \%)\end{array}$ & \\
\hline
\end{tabular}

Table 2. More young patients ( $<50$ years) were seen to be having malignant ascites i.e. $66.67 \%$ in comparison to just $33.3 \%$ of old patients ( $>50$ years) with malignant ascites

\begin{tabular}{|c|c|c|c|}
\hline Parameters & $\begin{array}{c}\text { Ascitic Fluid } \\
\text { Malignant } \\
\text { (Mean } \pm \text { S.D) }\end{array}$ & $\begin{array}{c}\text { Ascitic Fluid Non- } \\
\text { Malignant } \\
\text { (Mean } \pm \text { S.D) }\end{array}$ & P -value \\
\hline Age & $47.5 \pm 11.09$ & $55.78 \pm 10.82$ & 0.052 \\
\hline Ascitic Albumi & $2.38 \pm 0.25$ & $1.82 \pm 0.67$ & 0.003 \\
\hline Ascitic LDH & $523.58 \pm 127.62$ & $142.56 \pm 42.6$ & $<0.001$ \\
\hline Serum Albumi & $3.23 \pm 0.27$ & $3.94 \pm 0.62$ & 0.003 \\
\hline SAAG & $0.85 \pm 0.23$ & $2.14 \pm 0.49$ & 0.004 \\
\hline SGOT & $68.33 \pm 24.5$ & $28.72 \pm 6.22$ & $<0.001$ \\
\hline \multicolumn{5}{|c|}{ SGPT } & $65.20 \pm 22.4$ & $23.11 \pm 7.43$ & $<0.001$ \\
\hline Table 3. Comparison of Parameters in Malignant Ascites \\
and Non-Malignant Ascites \\
\hline \multicolumn{4}{|c}{}
\end{tabular}

\section{DISCUSSION}

Table 1 shows total no. of 12 patients with Ascites having malignancy were enrolled. The mean age of patient was 47.5 years. The youngest being 34 years old and oldest aged 70 years. 18 patients had ascites due to non-malignant causes. The youngest being 42 years and oldest 75 years. Initially, it was found that there was uniformly high levels of LDH in 
malignant effusions and low levels of LDH in non-malignant effusions. ${ }^{[6-9]}$ It was observed that the mean ascitic fluid LDH level was much lower in patients with liver diseases than in those with malignant ascites $(167 \pm 9$ vs $913 \pm 228 \mathrm{SU}) .{ }^{[10]} \mathrm{We}$ inferred a similar result from our study i.e. fluid LDH level in patients with malignant ascites was higher (523.8) as compared to fluid LDH level in non-malignant ascites (142.5) with a $\mathrm{p}$ value $<0.001$. The cut off values for three parameters in ascitic fluid for differentiation between hepatic and nonhepatic ascites are as follows: LDH of 400SU, fluid/serum LDH ratio of 0.6 , and fluid/serum total protein ratio of 0.5 . Ascitic levels higher than the cut offs for any two out of three parameters indicate a non-hepatic cause of ascites, whereas values below the cut offs for all three parameters strongly suggest a hepatic cause of ascites.

LDH values were higher in patients with an SAAG greater than $1.1 \mathrm{~g} / \mathrm{dL}$ or less than in those with a SAAG greater than $1.1 \mathrm{~g} / \mathrm{dL} .{ }^{[11,12]}$ We inferred a similar result from our study i.e. mean SAAG of 2.14 in patients with non-malignant ascites as compared to 0.85 in malignant ascites. However Sevinc et al. reported that in patients with malignant ascites, ascitic fluid LDH values had high sensitivity but low specificity for the diagnosis of the disease, and a low value of LDH did not necessarily exclude malignancy.[13] We inferred the same from our study i.e. Fluid LDH had a high sensitivity and specificity in differentiating malignant from non-malignant ascites. Of the 30 patients of ascites taken in our study 12 patients were found to have malignant ascites with a mean age of 47.5 years and the most common cause being liver cell carcinoma.[14-16] 18 patients were found to have nonmalignant ascites with mean age of 55.7 years and the most common cause being congestive cardiac failure.[17,18]

In our study we also found that the mean serum LDH values were higher in patients with malignant ascites (393) as compared to that of patients with non-malignant ascites (157) with a $p$ value of $<0.001$. The mean value of transaminases was raised in patients with malignant ascites which is similar to earlier studies.[19-22] In India, Pleural effusion occurs in a number of pathological conditions. ${ }^{[23]}$ It is important to classify pleural effusion as transudative or exudative as the primary diagnostic step because, if the effusion is a transudate, no further diagnostic procedures are necessary and therapy is directed towards the underlying disease process. If the effusion is exudative a more extensive diagnostic work-up is required to distinguish between the many possible causes of exudative effusion. ${ }^{[24-29]}$ In India, tubercular effusion is common. The various criteria that have been employed include pleural fluid specific gravity, protein levels and lactic dehydrogenase (LDH) levels. ${ }^{[30-34]}$ In patients with malignant cells in the pleural effusion, it was seen that LDH activity is higher than in the corresponding serum.[35] It was assumed that the increase in LDH activity is caused not only by the neoplastic cells which are proliferating in the effusion but also by the malignant tumours contiguous with the effusion. ${ }^{[36-37]}$ We inferred a similar result from our study i.e. mean fluid LDH levels were higher in exudative effusion (331) to that of transudative effusions (87) with a $p$ value of $<0.0001$.

In our study, we found that out of the 30 patients of pleural effusion taken for the study 17 patients were found to have exudative effusion and 13 patients were found to have transudative effusion. The average age of patients with exudative effusion was 51 years whereas 52.7 years in patients with transudative effusion. The mean serum LDH was also found to be higher in patients with exudative effusions (393) to that with transudative effusions (157) with $\mathrm{p}$ value $<0.0001$. In our study we found that the most common cause of transudative effusion in the study group was congestive heart failure and that of exudative effusion was Tuberculosis.

\section{CONCLUSION}

- Patients with malignant diseases show increased LDH activity in serum and malignant effusion.

- Estimating the fluid Lactate Dehydrogenase levels in patients presenting with ascites helps in differentiating between malignant and non-malignant effusion. It is highly sensitive (100\%) and highly specific (100\%).

- Estimating the fluid Lactate Dehydrogenase level in patients presenting with pleural effusion helps in differentiating between transudative and exudative effusion. It is highly sensitive (100\%) and highly specific (100\%).

Due to the relatively small study population, further studies with longer sample size are indicated to confirm the utility of fluid LDH in the diagnostic evaluation of ascites/ pleural effusion and to confirm the findings of our study.

\section{REFERENCES}

[1] American Thoracic Society. Management of malignant pleural effusions. Am J Respir Crit Care Med 2000;162(5):1987-2001.

[2] Antunes G, Neville E. Management of malignant pleural effusions. Thorax 2000;55(12):981-3.

[3] Glick JH Jr. Serum lactate dehydrogenase isoenzyme and total lactate dehydrogenase values in health and disease, and clinical evaluation of these test by means of discriminant analysis. Am J Clin Pathol 1969;52(3):320-8.

[4] Henderson RF, Harkema JR, Hotchkiss JA, et al. Effect of blood leucocyte depletion on the inflammatory response of the lung to quartz. Toxicol App Pharmacol 1991;109(1):127-36.

[5] Henderson RF, Driscoll KE, Harkema JR, et al. A comparison of the inflammatory response of the lung to inhaled versus instilled particles in F344 rats. Fundam Appl Toxicol 1995;24(2):183-97.

[6] Hagadom JE, Bloor CM, Yang MS. Elevated plasma activity of Lacatate Dehydrogenase isoenzyme-3 (LDH3) in experimentally induced immunologic lung injury. Am J Pathol 1971;64(3):575-84.

[7] Runyon BA, Montano AA, Akriviadis EA, et al. The serum ascites gradient is superior to the exudatestransudate concept in differential diagnosis of ascites. Ann Intern Med 1992;117(3):215-20.

[8] Sevinc A, Sari R, Fadillioglu E. The utility of Lactate dehydrogenase isoenzyme pattern in the diagnostic evaluation of malignant and non-malignant ascites. J Natl Med Assoc 2005;97(1):79-84.

[9] Romero S, Candela A, Martin C, et al. Evaluation of different criteria for separation of pleural transudates from exudates. Chest 1993;104(2):399-404. 
[10] Roth BJ, O'Meara TF, Cragun WH. The serum effusion albumin gradient in the evaluation of pleural effusions. Chest 1990;98(3):546-9.

[11] Marel M, Stastny B, Melinova L, et al. Diagnosis of pleural effusions: experience with clinical studies, 1986-1990. Chest 1995;107(6):1598-603.

[12] Sahn SA. State of the art. The pleura. Am Rev Respir Dis 1988;138(1):184-234.

[13] Richterich R, Burger A. Lactic dehydrogenase isoenzymes in human cancer cells and malignant effusions. Enzymol Biol Clin 1963;35:65-72.

[14] Vergnon JM, Guidollet J, Gateau 0, et al. Lactic dehydrogenase isoenzyme electrophoretic patterns in the diagnosis of pleural effusion. Cancer 1984;54(3):507-11.

[15] Lott JA, Nemensanszky E. Lactate dehydrogenase. In: Lott JA, Wolf PL, eds. Clinical enzymology, a case oriented approach. New York: Field, Rich \& Associated Inc., 1987: p. 213-44.

[16] Tuzun Y, Celik Y, Bayan K, et al. Correlation of tumour markers in ascitic fluid and serum: are measurements of ascitic tumor markers a futile attempt? J Int Med Res 2009;37(1):79-86.

[17] Shimada M, Berjohn C, Tanen DA. Ascites as the initial presentation of gastrointestinal carcinoma. J Emerg Med 2013;44(2):e195-e8.

[18] Hou W, Sanyal AJ. Ascites: diagnosis and management. Med Clin North Am 2009;93(4):801-7.

[19] Tarn AC, Lapworth R. Biochemical analysis of ascitic (peritoneal) fluid: what should we measure? Ann Clin Biochem 2010;47(Pt 5):397-407.

[20] Moss DW, Henderson AR. Enzymes. In: Burtis CA, Ashwood ER, eds. Tietz textbook of clinical chemistry. $2^{\text {nd }}$ edn. Philadelphia: Saunders Co., 1986: p. 735-896.

[21] Light RW. Useful tests on the pleural fluid in the management of patients with pleural effusions. Curr Opin Pulm Med 1999;5(4):245-9.

[22] Light RW. Management of pleural effusions. J Formos Med Assoc 2000;99(7):523-31.

[23] Cheng D, Rodriguez RM, Perkett EA, et al. Vascular endothelial growth factor in pleural fluid. Chest 1999;116(3):760-5.

[24] Zebrowski BK, Yano S, Liu W, et al. Vascular endothelial growth factor levels and induction of permeability in malignant pleural effusions. Clin Cancer Res 1999;5(11):3364-8.
[25] Wroblewski F, Wroblewski R. The clinical significance of lactate dehydrogenase activity of serous effusions. Ann Intern Med 1958;48(4):813-22.

[26] Runyon BA. Ascites. In: Schiff L, Schiff L, Schiff ER, eds. Diseases of the Liver. Philadelphia: Lippincott Company, 1993: p. 990-1015.

[27] Gines P, Quintero E, Arroyo V, et al. Compensated cirrhosis: natural history and prognostic factors. Hepatology 1987;7(1):122-8.

[28] D'Amico G, Garcia-Tsao G, Pagliaro L. Natural history and prognostic indicators of survival in cirrhosis. A systematic review of 118 studies. J Hepatol 2006;44(1):217-31.

[29] Planas R, Balleste B, Alvarez MA, et al. Natural history of decompensated hepatitis $C$ virus-related cirrhosis. A study of 200 patients. J Hepatol 2004;40(5):823-30.

[30] Mauer K, Manzione N. Usefulness of serum ascites albumin difference in separating transudate from exudative ascites. Another look. Dig Dis Sci 1988;33(10):1208-12.

[31] Boyer TD, Kahn AM, Reynolds TB. Diagnostic value of ascetic fluid lactate dehydrogenase, protein and WBC levels. Arch Intern Med 1978;138(7):1103-5.

[32] Pare P, Talbot J, Hoefs JC. Serum ascites gradient-a physiological approach to differential diagnosis of ascites. Gastroenterology 1983;85(2):240-4.

[33] Polak M, De Costa ACT, Bitelmann B. Diagnostic value of biochemical parameters (protein, glucose, cholesterol, mucoprotein, amylase) of ascetic fluid. Rev Hosp Clin Fac Med Sao Paulo 1978;33:186-99.

[34] Sood A, Garg R, Kumar R, et al. Ascitic fluid cholesterol in malignant and tubercular ascites. Journal of Association of Physicians in India 1995;43(11):745-7.

[35] Sampliner R, Iber F. High protein ascites in patients with uncomplicated hepatic cirrhosis. Annual Journal of Medical Sciences 1994;261:275-9.

[36] Jungst D, Xie Y, Gerbes AL. Pathophysiology of elevated ascetic fluid cholesterol in malignant ascetic. Increased ascites to serum relation of proteins and lipoproteins in patients with peritoneal carcinomatosis as compared to patients with cirrhosis of the liver. Journal of Hepatology 1992;14(2-3):244-8.

[37] Light RW. The light criteria: the beginning and why they are useful 40 years later. Clin Chest Med 2013;34(1):21-6. 